\title{
Leptosphaeria maculans Elicits Apoptosis Coincident with Leaf Lesion Formation and Hyphal Advance in Brassica napus
}

\author{
Caixia Li, ${ }^{1}$ Susan J. Barker, ${ }^{1}$ David G. Gilchrist, ${ }^{2}$ James E. Lincoln, ${ }^{2}$ and Wallace A. Cowling ${ }^{1,3}$ \\ 'School of Plant Biology M084, The University of Western Australia, 35 Stirling Highway, Crawley, WA 6009 AUSTRALIA; \\ ${ }^{2}$ Department of Plant Pathology, University of California, Davis 95616, U.S.A.; ${ }^{3}$ Canola Breeders Western Australia Pty Ltd., \\ 15/219 Canning Highway, South Perth, WA 6151, Australia
}

Submitted 11 January 2008. Accepted 28 April 2008.

Programmed cell death, with many of the morphological markers of apoptosis, is increasingly recognized as an important process in plant disease. We have investigated the involvement and potential role of apoptosis during the formation of leaf lesions by the fungus Leptosphaeria maculans on susceptible Brassica napus cv. Westar. There were no signs of host cell damage until 7 to 8 days postinoculation (dpi), when trypan-blue-stained leaf mesophyll cells were first detected. Hyphae were visible in the intercellular spaces of the inoculated area from $5 \mathrm{dpi}$ and were associated with trypan-blue-stained cells at 8 to 9 dpi. Hallmarks of apoptosis, observed coincident with or immediately prior to the formation of leaf lesions at 8 to $10 \mathrm{dpi}$, included membrane shrinkage of the mesophyll cell cytoplasm, loss of cell to cell contact in mesophyll cells, and terminal deoxynucleotidyl transferase-mediated dUTP nick end labeling of nuclei in apparently "healthy" tissue immediately adjacent to dead areas. Hyphae were highly branched and prolific in the "healthy" tissue immediately adjacent to dead areas 9 to $10 \mathrm{dpi}$, and formed pycnidia inside dead areas 11 to $12 \mathrm{dpi}$. Coinfiltration of the tetrapeptide caspase inhibitor Ac-DEVD-CHO with spores of the pathogen significantly suppressed development of leaf lesions but did not affect fungus viability. We hypothesize that $L$. maculans elicits apoptosis as a dependent component of pathogenesis in susceptible $B$. napus, and that the fungus uses apoptotic cells as a source of nutrition for reproduction and further growth.

Additional keywords: blackleg, canola, endophytic, necrotrophic, Phoma canker, saprophytic.

The fungus Leptosphaeria maculans (Desm.) Ces. \& De Not. causes a disease on leaf, stem, and crown tissues of oilseed rape or canola (Brassica napus L.) known as Phoma canker or blackleg (Punithalingam and Holliday 1972) which is of worldwide importance (Fitt et al. 2006). The fungus switches between saprophytic, necrotrophic, and endophytic phases of existence, depending on the substrate with which it is associated (Rouxel and Balesdent 2005). During the leaf infection

Corresponding author: Wallace A. Cowling;

E-mail: wcowling@cyllene.uwa.edu.au

* The e-Xtra logo stands for "electronic extra" and indicates that a supplemental figure is published online. phase on B. napus, the pathogen is generally described as necrotrophic (Rouxel and Balesdent 2005), after which the fungus reproduces asexually within the dead leaf or cotyledonary tissue, thereby providing secondary inoculum for continuing infection cycles. Within the plant, the disease spreads from the leaf lesions by systemic colonization of leaf and stem tissues. The fungus subsequently invades the crown of the plant, where it causes further death in the form of a canker and where sexual reproduction occurs. The blackened canker may completely girdle the base of the stem, causing crop lodging and substantial economic loss in seed yield (Hammond and Lewis 1986, 1987; Hammond et al. 1985; Howlett 2004).

It has been difficult to classify plant pathogens as biotrophs or necrotrophs and various molecular explanations for these terms have arisen (Oliver and Ipcho 2004). There is accumulating evidence that programmed cell death (PCD), showing hallmarks of apoptosis, is involved in many compatible hostpathogen interactions that have been classified as necrotrophic (Gilchrist 1997; Gilchrist et al. 2002; Harvey et al. 2008; Hoat et al. 2006; Kiba et al. 2006; Navarre and Wolpert 1999; Samadi and Behboodi 2006; Wang et al. 1996; Yao et al. 2001, 2002). Furthermore, in a number of compatible host-pathogen interactions, initiation of death of the host cells occurs in advance of microbial growth (Gilchrist 1998; Richael and Gilchrist 1999; Wolpert et al. 2002). In this context, it has been proposed that some, if not all, necrotrophic pathogens induce plant cells to actively undergo death as a prerequisite for infection of host plants (Richael et al. 2001), with the dying cells exhibiting some of the morphological markers of apoptosis, depending on when the images are captured. These PCD markers include DNA ladders, nuclear shrinkage, formation of DNA bodies in dying cells, and nuclear DNA fragmentation detected in situ by terminal deoxynucleotidyl transferase-mediated dUTP nick end labeling (TUNEL) reaction (Gavrieli et al. 1992).

Another key feature of apoptosis in animals is the activation of a specific group of proteases, known as caspases (cysteine aspartate proteases), leading to the systematic cleavage of a set of cell-stabilizing proteins (the caspase cascade), culminating in the orderly disassembly of cells (Green 1998; Grütter 2000; Hengartner 2000; Nicholson and Thornberry 1997). This orderly dismantling of cells maintains integrity of the plasma membrane until internal organelles and potentially harmful contents including phenolics, reactive oxygen, and hydrolytic enzymes have been rendered harmless to contiguous cells, thus avoiding inflammatory responses (Sánchez-Alcázar et al. 2007). Caspases are highly conserved in structure and function and can be 
found across the animal kingdom from humans to insects and nematodes (Earnshaw et al. 1999; Meier et al. 2000). Initial sequence search algorithms have not identified close homologs of animal caspases in plants (Woltering et al. 2002). However, recent reports of functional assays confirm the existence of caspase-like proteases in plants (Bozhkov et al. 2005; Chichkova et al. 2004; Lam 2005; Lombardi et al. 2007) and a vacuolar processing enzyme (VPE $\gamma$ ) has been reported in Arabidopsis thaliana with activity resembling mammalian caspase-1 (Kuroyanagi et al. 2005; Rojo et al. 2004).

All caspases have a high degree of substrate specificity virtually unique among eukaryote proteases and are undoubtedly a key to the orderly manner of cell death that they initiate. Cleavage occurs only after an aspartic acid and requires the presence of a recognition sequence $\mathrm{N}$-terminal to the cleavage site that is four or more amino acids long (Grütter 2000). Small peptidebased inhibitors have been used to block the catalytic ability of caspases with specificity determined by mimicking the tetrapeptide substrate recognition site (Garcia-Calvo et al. 1998). For example, DEVD and YVAD are tetrapeptide substrates for caspase-3 and caspase-1, respectively. Caspase activity can be blocked by tetrapeptide substrates coupled to aldehyde (CHO: reversible inhibitor) or methylketone radicals (CMK and FMK: irreversible inhibitors) (Garcia-Calvo et al. 1998; Wei et al. 2000). These cell-permeable inhibitors can delay or prevent apoptosis in animal systems and also inhibit caspase 1-like activity of VPE $\gamma 1$ in plants (Kuroyanagi et al. 2005; Rojo et al.
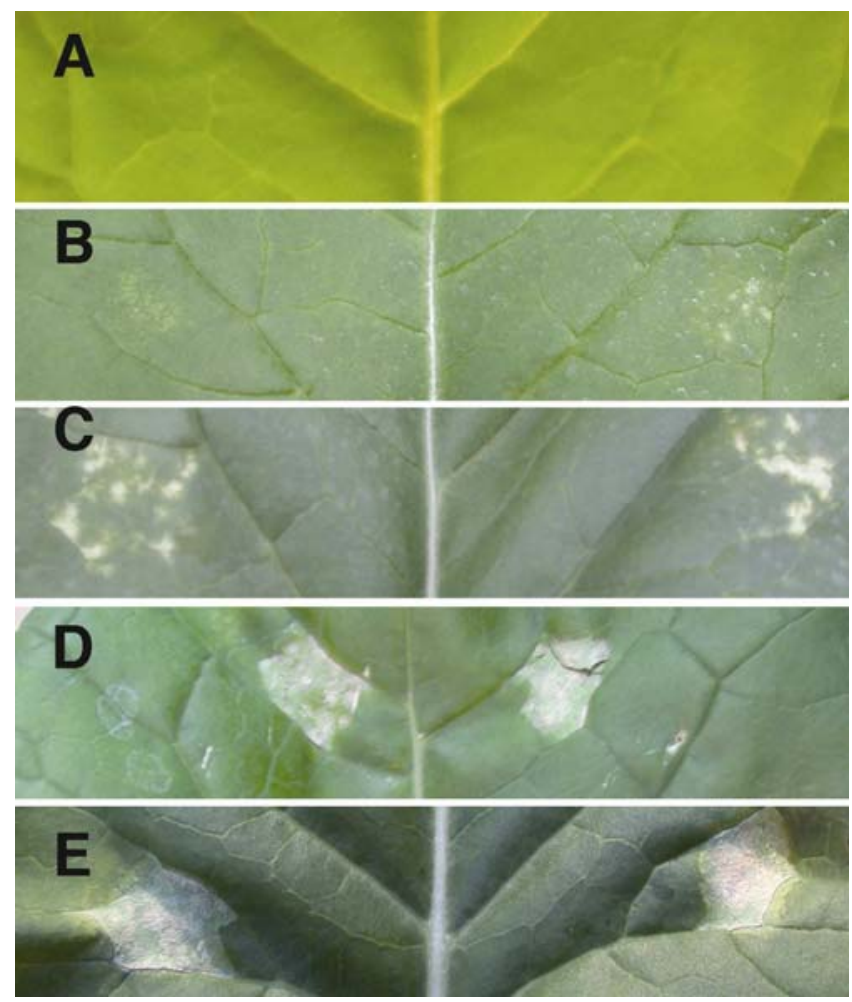

Fig. 1. Symptoms on leaves of susceptible Brassica napus cv. Westar from 7 to 20 days postinoculation (dpi) with Leptosphaeria maculans. Plants were inoculated by infiltrating approximately $100 \mu \mathrm{l}$ of pycnidiospore suspension at $10^{5}$ spores per milliliter on each side of the midvein of the third expanded leaf of 4-week-old seedlings. A, No symptoms were apparent up to 7 to $8 \mathrm{dpi}$. B, Pin-prick size gray spots appeared at 9 to $10 \mathrm{dpi}$ in the area of infiltration. $\mathbf{C}$, Small localized lesions of bleached necrotic tissue were visible throughout the inoculated area at 11 to $12 \mathrm{dpi}$. D, Necrotic lesions filled the entire inoculated areas by 13 to $14 \mathrm{dpi}$, and immature pycnidia were developing inside lesions. E, Lesions spread beyond the inoculation area by $20 \mathrm{dpi}$. The diameter of the infiltrated area of leaf tissue and subsequent lesions was approximately $1 \mathrm{~cm}$ in each photograph.
2004). Ac-DEVD-CHO, Ac-VEID-CHO, and Ac-YVAD-CHO were effective in inhibiting caspase-3-, caspase-6-, and caspase1-like activity, respectively, in Phaseolus coccineus suspensor cells (Lombardi et al. 2007).

Coinfiltration of tetrapeptide inhibitors of caspase enzymes from animal systems, such as Ac-DEVD-CHO, reduced plant cell death and disease symptoms on susceptible tobacco caused by the plant-pathogenic bacterium Pseudomonas syringae pv. tabaci (Richael et al. 2001). Some natural caspase inhibitors, such as the cowpox serpin CrmA and the caspase inhibitor p35 from baculovirus, are able to specifically block caspase activity (Stennicke and Salvesen 1998). Further evidence supporting trans-kingdom conservation of proteins functioning in the process derives from the transgenic expression of specific anti-apoptotic animal genes, the expression of which leads to inhibition or suppression of cell death and disease susceptibility to several necrotrophic pathogens in plants as well as death triggered by several abiotic stress stimuli. For example, transgenic tobacco and tomato plants expressing anti-apoptotic genes, including baculovirus p35, IAP, human Bcl-2, and nematode CED-9, blocked disease development and resulted in resistance to a wide range of fungal, viral, and bacterial plant pathogens (Chen and Dickman 2004; Dickman et al. 2001; Gilchrist et al. 2001; Harvey et al. 2008; Lincoln et al. 2002; Mitsuhara et al. 1999; Qiao et al. 2002; Richael et al. 2001; Xu et al. 2004). These results support the hypothesis that PCD, with functional conservation of apoptosis, occurs during plant development and in host-pathogen interactions as an integral part of plant pathogenesis.

Our aim was to characterize the mechanism by which the blackleg fungus kills susceptible $B$. napus cells during the leaf infection phase and, thereby, obtains nutrition for primary growth and asexual reproduction. We hypothesized that the pathogen induces an orderly process of cell disassembly (with hallmarks of apoptosis) providing for a gradual release of nutrients for hyphal absorption. To test this hypothesis, we combined microscopic observation of the pattern of plant cell death during infection and the relationship between fungal growth and host cell death with i) TUNEL reaction to test for DNA fragmentation, ii) whole-tissue DNA isolation to observe DNA laddering, and iii) assessment of disease symptoms following coinfiltration of fungal spores with the caspase inhibitor Ac-DEVD-CHO. Our results provide evidence for the involvement of PCD, exhibiting characteristics of apoptosis, in the death of cells in the compatible interaction of L. maculans with $B$. napus that is coincident with or immediately prior to lesion formation and hyphal advance in leaf tissue.

\section{RESULTS}

\section{Progression of fungal growth and the pattern of plant cell death in relation} to symptom development in B. napus cv. Westar.

Using a pipette infiltration procedure, we inoculated approximately 1,500 conidia into an area of approximately $1 \mathrm{~cm}^{2}$, conditions that had been determined in preliminary experiments to produce lesions reliably and in a manner consistent with field observations in terms of both timing and appearance. Symptoms first appeared as small gray collapsed areas of leaf tissue 9 days postinoculation (dpi) by leaf infiltration, and rapidly coalesced to form several lesions by $11 \mathrm{dpi}$ that were 2 to $3 \mathrm{~mm}$ in diameter, pale-green with diffuse margins, and appeared dehydrated (Fig. 1). Dead or dying tissue filled the entire inoculated areas by 13 to $14 \mathrm{dpi}$ and pycnidia were observed in the dead zones. By $20 \mathrm{dpi}$, lesions had spread beyond the border of the inoculated area (Fig. 1). These observations are typical of field symptoms of this disease, and indicate that a normal 

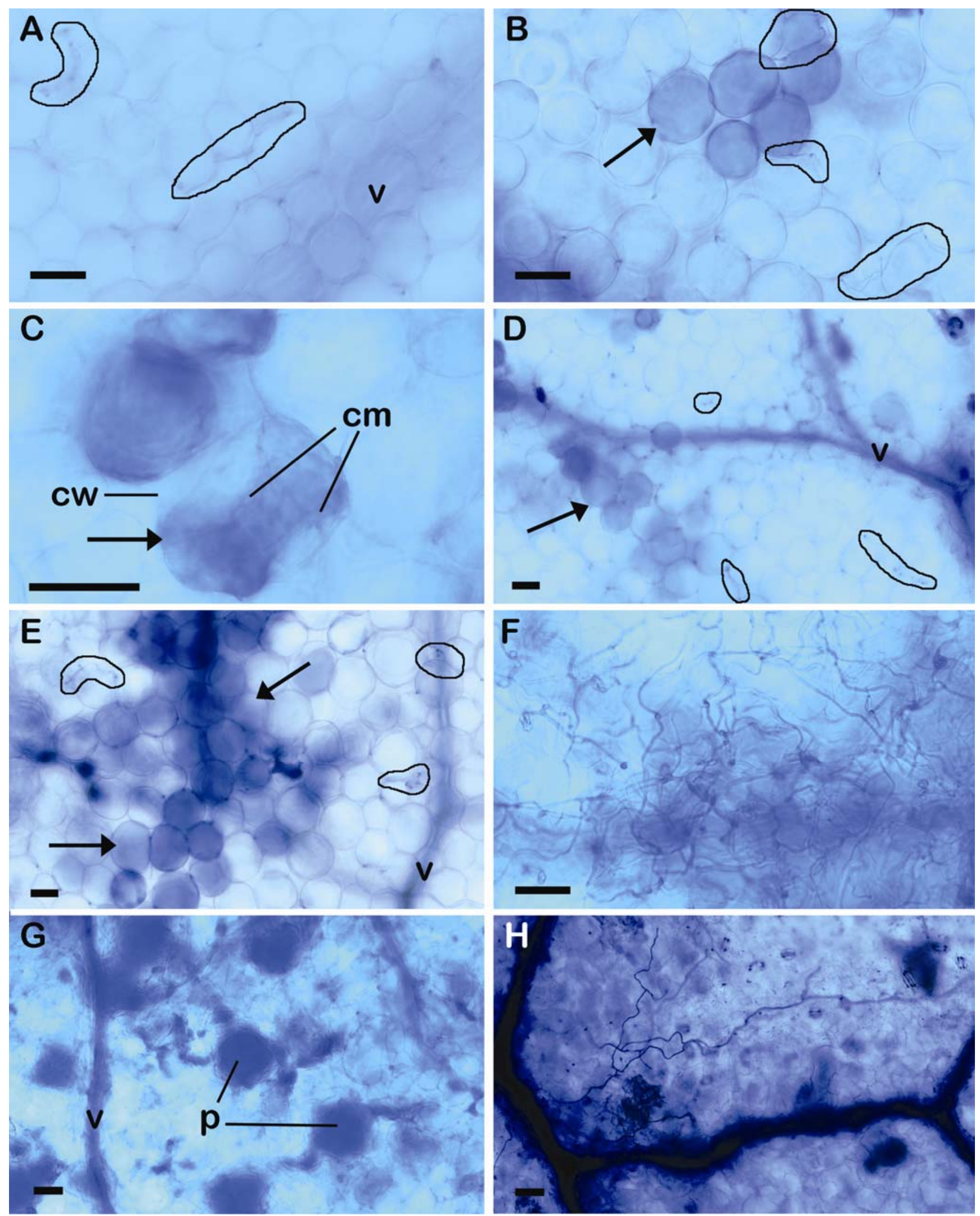

Fig. 2. Pattern of fungal growth and plant cell death in relation to symptom development in leaf tissue of Brassica napus cv. Westar inoculated with Leptosphaeria maculans by the leaf infiltration method then stained with trypan blue and directly visualized by light microscopy. Hyphae stain deep purple and are not much thicker than the cell wall. Hyphal strands running through or along the plane of the sections are ringed with black; arrows indicate deeply stained cells. A, Hyphae growing in intercellular spaces of infiltrated leaf tissue at 5 days postinoculation (dpi). B, Small cluster of deeply stained mesophyll cells at $7 \mathrm{dpi}$, and a few hyphae in intercellular spaces. C, Higher magnification of deeply stained cells showing membrane shrinkage away from cell wall. D and $\mathbf{E}$, Cluster of deeply stained mesophyll cells adjacent to hyphae at 8 to 9 dpi. F, Abundant hyphae in asymptomatic tissue between small visible lesions at 11 dpi. G, Pycnidia developing inside collapsed tissue at 12 dpi. H, Hyphae growing beyond the border of the original infiltration area and beyond the visible lesion at 20 dpi. Abbreviations: cm, cell membrane; cw, cell wall; p, pycnidium; v, leaf vein. Bars: $50 \mu \mathrm{m}$. 
"compatible" interaction occurred between the susceptible $B$. napus cv. Westar and the isolate of L. maculans used in the leaf infiltration inoculation procedure.

Microscopic observations in vivo correlated plant cell death to growth of L. maculans and macroscopic leaf symptom development. Germinated pycnidiospores were observed 3 dpi in the infiltration area of leaf tissue (data not shown). A few hyphae were observed by 5 to 6 dpi inside the intact leaf tissue in the infiltration area, which grew mainly along the veins and extended to intercellular spaces of the mesophyll (Fig. 2A). At this stage, there was no obvious damage to host cells (no cells stained with trypan blue) in either inoculated or water-infiltrated tissue.

By 7 to $8 \mathrm{dpi}$, prior to the formation of visible leaf lesions, some deeply stained mesophyll cells, indicative of a loss of cell membrane permeability, appeared in areas colonized by the fungus (Fig. 2B, arrow). The membranes of these cells began to retract from the cell wall (Fig. $2 \mathrm{C}$ ). This retraction of the plasma membrane from the cell wall was simultaneously observed in the semithin cross sections (Fig. 3A). The deeply stained mesophyll cells occurred sparsely at first, then increased over time, eventually coalescing into clusters of deeply stained cells by 8 to
9 dpi (Fig. 2D and E), coincident with small localized lesions observed by 9 to 10 dpi (Fig. 1). A dense hyphal network was present between small localized lesions at 11 dpi (Fig. 2F). Hyphae were also visible in apparently healthy tissue beyond the border of the lesion at $20 \mathrm{dpi}$ (Fig. $2 \mathrm{H}$ ).

In semithin sections from inside the inoculation area, the cytoplasmic membrane of affected mesophyll cells was observed to shrink away from the cell wall. This is most clearly visible in Figure 3A. The cytoplasmic membrane appeared to be intact around these shrunken cells. Cell-to-cell contact was disrupted, with evidence of remnants of dead or dying cells in large empty spaces on tissue sections (Figs. 3B through D). Some cells were filled with hyphae at this stage of infection (11 dpi) (Fig. 3D).

Many pycnidia were produced inside the dead tissue after 11 to 12 dpi (Fig. 2G). By 13 to $14 \mathrm{dpi}$, when lesion formation had engulfed the entire infiltration area (Fig. 1), fewer hyphae were visible inside the lesions. The hyphae on the surface of the lesions were less branched than had been observed early in the infection process. At 20 dpi, hyphae were observed several millimeters beyond the border of the original infiltration area and had spread beyond the border of visible lesions (Fig. 2H).
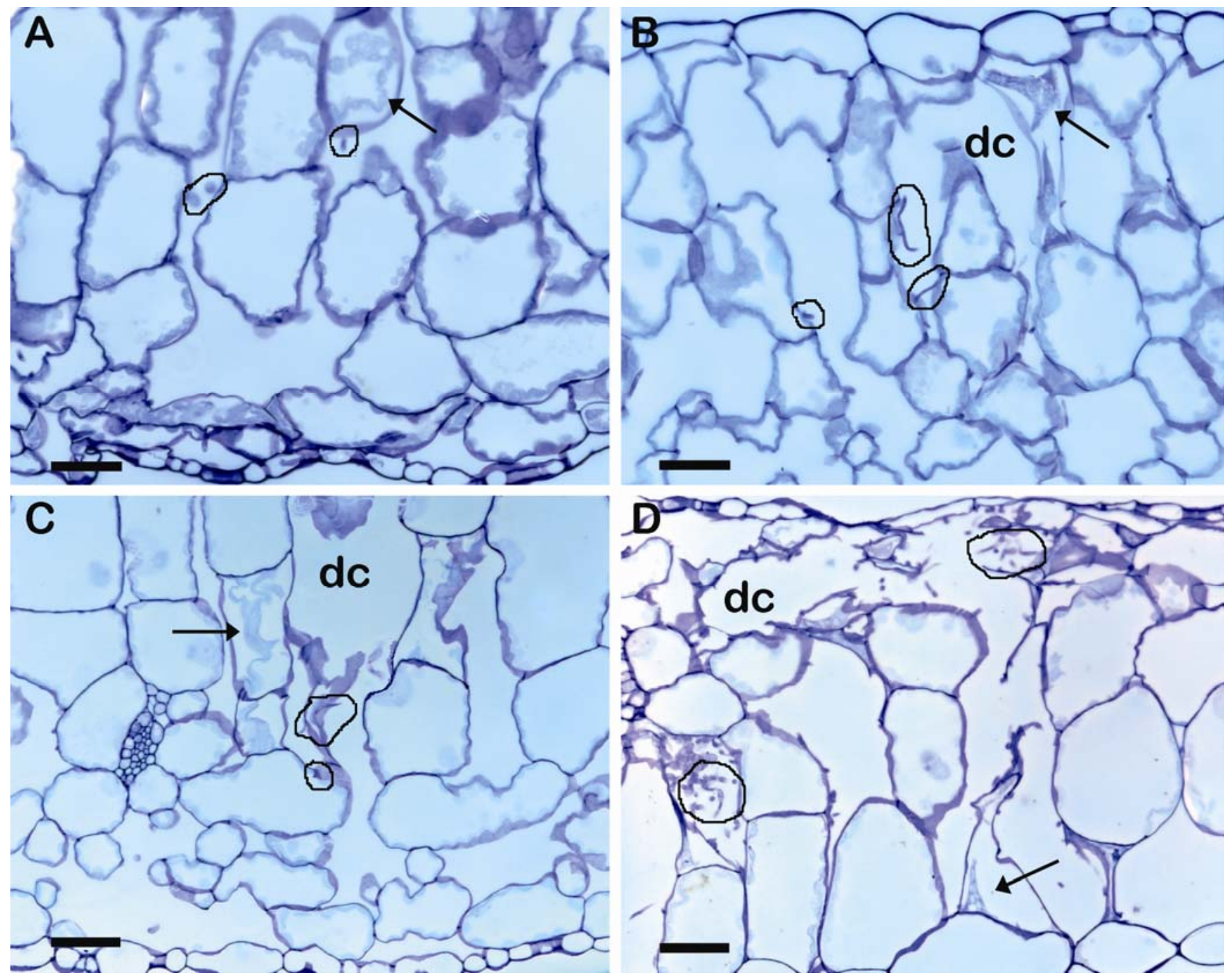

Fig. 3. Semithin cross sections showing the process of plant cell death in leaf tissue of Brassica napus cv. Westar inoculated with Leptosphaeria maculans by the leaf infiltration method at $10^{5}$ spores $/ \mathrm{ml}$. The sections were stained with $0.5 \%$ toluidine blue $\mathrm{O}$, $\mathrm{pH} 4.4$. Hyphal strands are ringed with black. A, Cytoplasmic membrane retracted from cell wall at 7 days postinoculation (dpi) (arrow). B, C, and D, Plant cell death at different stages ( 0 to 11 dpi). Arrows point toward cells with membrane shrinkage and retraction of the cytoplasmic membrane from the cell wall and "dc" indicates dead cells or spaces between cells with remnants of dead or dying cells (representing loss of cell to cell contact in mesophyll cells). Bars: $50 \mu \mathrm{m}$. 
Together, these observations showed that abundant hyphae were associated with cells that had visible hallmarks of apoptosis, and that dead plant cells no longer directly supported vigorous fungal growth but were now the site of differentiation into reproductive tissue.

Visual characterization of apoptotic cells by TUNEL assay. Cell death was visible under the microscope by 7 dpi, 2 to 3 days prior to visible lesions (Figs. 1 through 3 ). To test the hypothesis that cell death in individual cells prior to visible lesion formation was occurring via an apoptotic-like process, we used the TUNEL reaction to detect DNA cleavage in nuclei of infiltrated leaf sections at $10 \mathrm{dpi}$, when tissue inoculated with the fungus was showing early signs of lesion development. To rule out possible artifacts caused by inappropriate reagent application and tissue handling, positive (fungal spore), negative (water), and noninoculated controls were included in every experiment. Strong positive TUNEL reactions were obtained in the control female rodent mammary gland tissue (Supplementary Fig. 1). Nuclei in cells of the water control showed distinct fluorescent signals following 4'-6-diamino-2phenylindole (DAPI) staining (Fig. 4A) but did not exhibit a positive TUNEL reaction, indicating that the nuclei were intact (Fig. 4B). Some cells in inoculated tissue showed abnormally strong but somewhat diffuse blue fluorescence and diminished auto fluorescence, which are signs of cell damage or death (Fig. 4C). However, a strong positive TUNEL signal was always detected in nuclei of a few cells adjacent to lesions, indicating that DNA fragmentation had occurred within the nuclei of these apparently healthy cells (Fig. 4D) and that the cells were irreparably damaged and progressing on the path of PCD. Between five and nine cells with TUNEL-positive signals were present in all eight sections examined. This result supports our hypothesis that $L$. maculans-associated plant cell death occurs by an apoptotic process.

\section{DNA laddering.}

We were unable to detect clear signs of DNA laddering in DNA isolated from the leaf infiltration area immediately before and immediately after symptom appearance (gels not shown).
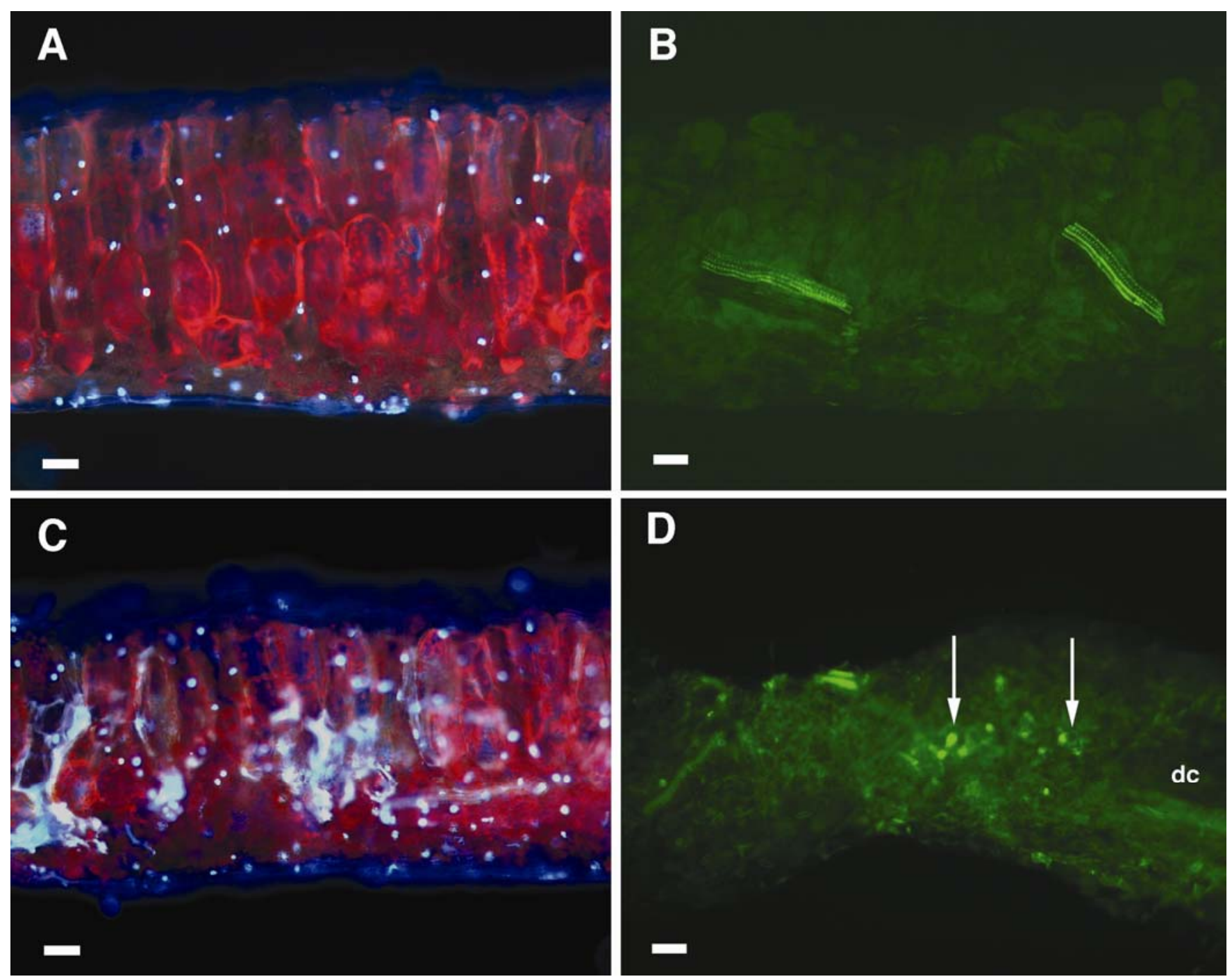

Fig. 4. Result of terminal deoxynucleotidyl transferase-mediated dUTP nick end labeling (TUNEL) analysis on 20- to 30- $\mu \mathrm{m}$ thick sections of susceptible Brassica napus cv. Westar leaves inoculated with Leptosphaeria maculans spores by the leaf infiltration method, 10 days postinoculation. A, Water control stained with 4'-6-diamino-2-phenylindole (DAPI) showing bright light blue DAPI-stained nuclei. B, Water control following the TUNEL reaction. No positive TUNEL signal was detected in nuclei, indicating that no DNA fragmentation had occurred. C, Fungal-infected leaf section stained with DAPI showing bright blue DAPI-stained nuclei with dye migration indicative of DNA degradation. D, Fungal-infected leaf section following TUNEL reaction. Arrows indicate strong positive TUNEL signals in nuclei of a few cells adjacent to the dead area, which indicates that DNA fragmentation had occurred within the nuclei of these cells; dc, dead cells. Bars: $50 \mu \mathrm{m}$. 
The pattern of cell death observed microscopically was initially scattered and subsequent death of cells outside coalescent dead areas was asynchronous, with no more than $10 \%$ of the cells showing the DAPI-TUNEL differential at any point in time within a given viewing field. In retrospect, it is unlikely that sufficient numbers of dying cells retained adequate amounts of small molecular weight DNA fragments of $180 \mathrm{bp}$ compared with mostly intact DNA outside or totally degraded DNA inside the margin of the lesion.

\section{The effect of caspase inhibitor on leaf lesion development.}

To further test the role of PCD in host symptom development during the susceptible interaction, we examined the coinfiltration of inoculum with the caspase tetrapeptide substrate Ac-DEVD-AMC and the inhibitor Ac-DEVD-CHO. There was no significant difference between the lesion area in the "+AMC" and "fungus-only" treatments (Fig. 5), indicating that the caspase substrate had no effect on lesion formation. In contrast, coinfiltration of spores with the caspase inhibitor ("+CHO treatment") significantly reduced the size of leaf lesions caused by L. maculans on B. napus cv. Westar (Fig. 5). No symptoms occurred on the water-only controls with or without inhibitor or substrate versions of the tetrapeptide DEVD.

\section{Analysis of the effect of caspase inhibitor and the tetrapeptide substrate on fungal growth.}

We tested the direct effect of the tetrapeptide DEVD on the fungus in two ways. First, spores were germinated in the presence of the caspase tetrapeptide substrate or inhibitor. Spore germination in vitro was 75 to $80 \%$ in all treatments $(+\mathrm{CHO}$, $+\mathrm{AMC}$, and fungus only), with no significant differences among treatments (data not shown). Ac-DEVD-CHO neither reduced spore germination nor caused abnormal growth of germ tubes in vitro. Second, leaf discs infiltrated with $+\mathrm{CHO}$, $+\mathrm{AMC}$, and fungus only were excised $2 \mathrm{dpi}$ and incubated on water agar for 7 days. Hyphae emerged from all discs, and growth on water agar gave rise to hyphal colonies with an average diameter of $3.4 \mathrm{~cm}$ at 7 days, with no significant differences between treatments. Leaf symptoms were reduced by tetrapeptide inhibitor (Fig. 5) but fungal growth from leaf discs coinfiltrated with tetrapeptide inhibitor on water agar and spore germination was not inhibited.

\section{DISCUSSION}

The results of this study support the involvement of PCD, with some of the hallmarks of apoptosis, in leaf lesion development caused by a compatible isolate of $L$. maculans on susceptible B. napus cv. Westar. The hallmarks of apoptosis, which were detected before leaf lesions were visible, include membrane shrinkage of the mesophyll cell cytoplasm, loss of cell-to-cell contact in mesophyll cells, and nuclear DNA fragmentation. Additional supportive evidence includes a reduction in cell death and leaf lesion formation by coinfiltration with the specific tetrapeptide caspase inhibitor Ac-DEVD-CHO but not with the substrate Ac-DEVD-AMC at concentrations consistent with the inhibitor's effect on caspases in animal systems.

Hyphae were seen in the vicinity of host cells showing visible hallmarks of apoptosis prior to visible lesion formation at 9 to 10 dpi (Figs. 2 through 4). Such host cells were not necessarily in physical contact with mycelium, nor were they visible outside of the inoculation area. This process of death in B. napus leaf cells is distinguished from necrosis in which the cell membrane ruptures early in cell death and the cell contents are released immediately (Gilchrist 1998), or related definitions which involve the release of large quantities of cell-walldegrading enzymes (Oliver and Ipcho 2004). Our observations suggest that cell death associated with the compatible interaction of B. napus with L. maculans is an orderly process that is actively stimulated by the fungus. This hypothesis has a logi-

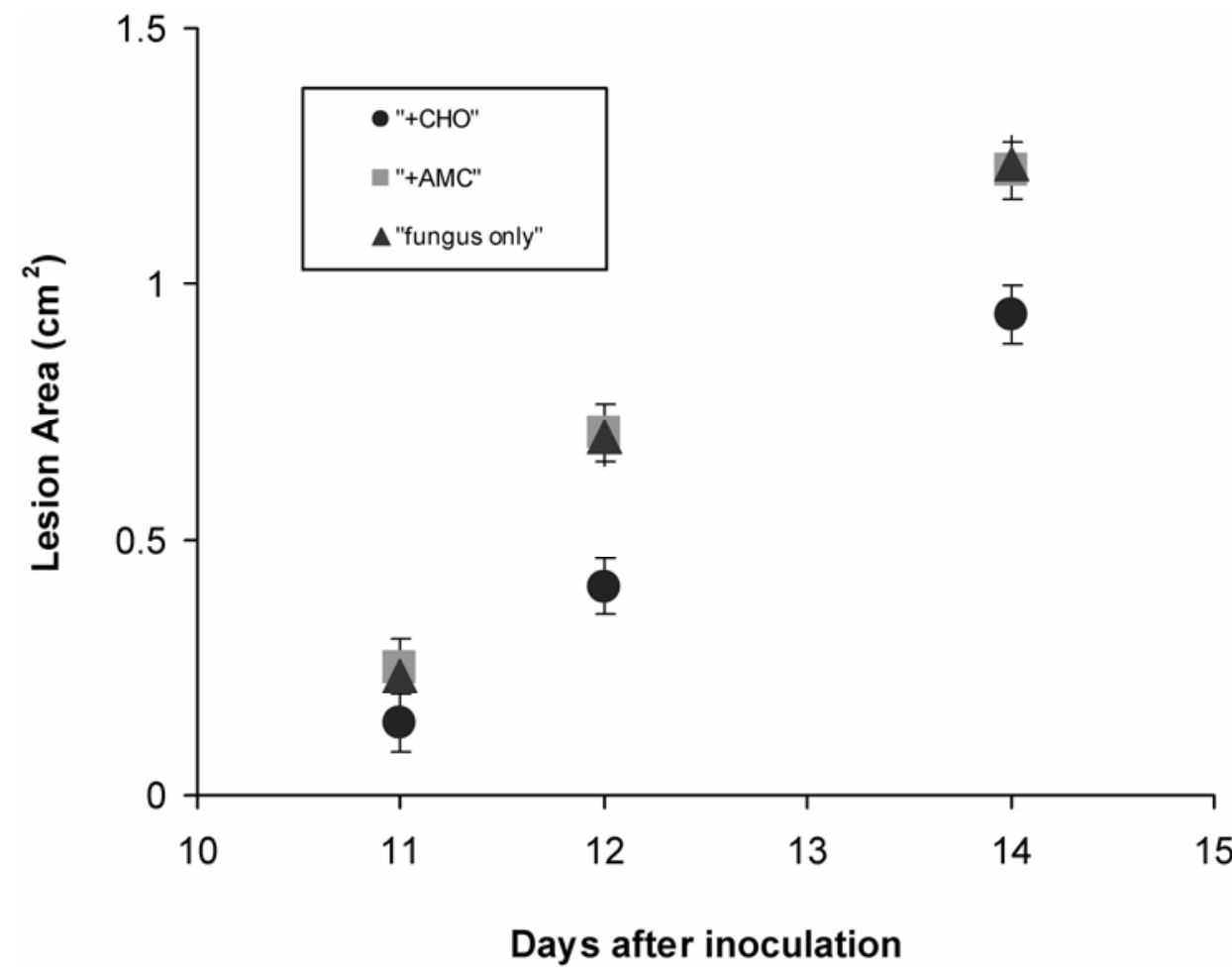

Fig. 5. Effect of adding caspase inhibitor Ac-DEVD-CHO ("+CHO") and substrate Ac-DEVD-AMC ("+AMC") to the inoculation mixture, compared with "fungus-only" treatment, on the area (in square centimeters) of leaf lesions on Brassica napus cv. Westar inoculated with Leptosphaeria maculans at $10^{5}$ spores $/ \mathrm{ml}, 11$ to 14 days postinoculation. Data points are means \pm standard error. 
cal extension that the fungus acquires nutrients for growth from cells undergoing apoptosis but before the cells collapse. This ensures an orderly process of cellular dismantling that does not permit antifungal compounds to be released from cells and does not disrupt fungal growth; the analogy in animals is cell death caused by necrosis which is accompanied by tissue inflammation versus the orderly process of apoptosis which avoids tissue disruption (Kerr et al. 1972).

\section{Leaf-infiltration method.}

The leaf-infiltration method for inoculation of seedling leaves was used for several reasons. i) It allowed titration of inoculum concentrations to a level leading to reproducible development of individual leaf lesions characteristic of field disease. Such low concentrations of inoculum might be expected under natural field infections and avoided potential artifacts in experiments conducted at artificially high inoculum concentrations. ii) It enabled the inoculated area of leaf tissue to be defined by a marker pen, so that microscopic changes due to presence of the fungus could be readily observed inside and outside the inoculated area. Finally, iii) it allowed simultaneous exposure of leaf lamina to fungal development and effector compounds for analysis of host cell changes prior to lesion development. With this method, we produced symptoms of disease at $10^{3}$ pycnidiospores per milliliter (data not shown), equivalent to 10 to 15 pycnidiospores $/ \mathrm{cm}^{2}$ of leaf infiltration area, which is four orders of magnitude lower concentration than previously used by Fristensky and associates (1999). The leaf lesions formed by this method were consistent with field symptoms in both latent period and symptom appearance (Hammond and Lewis 1986, 1987; Hammond et al. 1985).

\section{Identification of apoptotic cells \\ by TUNEL assay and DNA laddering.}

DNA laddering, another hallmark of apoptosis, was not observed in this study; however, this is not surprising given the transient nature of apoptotic cell death (Wyllie et al. 1980) and the difficulty of isolating sufficient cells at the appropriate stage of apoptosis to observe such DNA laddering on a gel. Our previous experience in detecting ladders in protoplasts or leaf tissue treated with sphingosine analog mycotoxins indicated that approximately $50 \%$ of the activated cells needed to be dying synchronously (TUNEL positive) and extracted before cells were dead in order to observe distinct ladders (Wang et al. 1996). The transient nature of apoptotic cell death also explains the low frequency of TUNEL-reacting nuclei, with up to eight nuclei per thin section in a narrow band of tissue adjacent to collapsed tissue, in contrast to at least 100 nuclei visible under UV light in healthy tissue in the same focal areas. DNA ladders have been observed in plant cells undergoing PCD most readily when synchrony of the death of large numbers of cells could be induced by use of cell cultures or use of purified toxin in whole-leaf tissue (Navarre and Wolpert 1999; Wang et al. 1996; Yao et al. 2001, 2002).

\section{The effect of caspase inhibitor on leaf lesion development.}

The animal caspase tetrapeptide inhibitor Ac-DEVD-CHO reduced average lesion area but the homologous caspase substrate Ac-DEVD-AMC had no effect on lesion area (Fig. 5), indicating that the inhibitory effect was due to the - $\mathrm{CHO}$, as opposed to $-\mathrm{COOH}$, on the terminal aspartate and not the peptide alone. We conclude that suppression of death resulted from the blocking of a caspase-like activity in the plant leaf as described by others (Kuroyanagi et al. 2005; Rojo et al. 2004). Our experiments involved a single coinfiltration of inhibitor with spores at $0 \mathrm{dpi}$, at low inhibitor concentrations that are known to be biologically significant in terms of caspase inhibi- tion (discussed in the following paragraph), and yet the impact of the inhibitor was observed 9 to 10 days later when symptoms first appeared. Either the inhibitor has an effect that lasts for at least a week or the processes that are affected by the inhibitor begin very soon after inoculation and are critical for infection to proceed; either way, the inhibitor ultimately suppresses the development of symptoms.

The properties of Ac-DEVD-CHO in inhibiting caspase enzymes and apoptosis were discovered in animal systems (Nicholson et al. 1995). This animal caspase inhibitor was found to reduce disease symptoms in tomato, tobacco, bean, and pea caused by pathogenic bacteria (Richael et al. 2001). In that study, Ac-DEVD-CHO was used at $500 \mu \mathrm{M}$ and substantially inhibited disease development at an inoculum concentration that reproduced the field-level disease symptoms. In the research reported here, Ac-DEVD-CHO was effective at 100 $\mu \mathrm{M}$, a caspase-inhibiting concentration as reported in the animal apoptosis literature, and at low L. maculans inoculum concentrations that reproduced field-level disease symptoms. No evidence was found to suggest that fungal growth was affected by the caspase inhibitor Ac-DEVD-CHO in vitro or in vivo, which indicates that the tetrapeptide inhibitor was not directly detrimental to the fungus. This result extends the range of plant diseases for which Ac-DEVD-CHO can reduce symptoms and for which PCD is likely to be involved in compatible plant-microbe interactions.

\section{Fungal nutrition in diseased tissue.}

Fungal growth patterns are closely related to nutrient availability. When nutrients are scarce, fungal hyphae are sparse and thin, with large distances between the branches. This morphology has been described as "hunger mycelium" (Jennings and Lysek 1996). In nutrient-rich habitats, the number of branches and density of mycelia increase (Jennings and Lysek 1996). At the beginning of infection in this study, intercellular hyphae were long and minimally branched, typical of hunger mycelia (Fig. 2A). By the time small lesions were visible, hyphae were abundant in "healthy" areas adjacent to small dead areas of tissue (Fig. 2F), positive TUNEL signals were detected in cells adjacent to the dead areas (Fig. 4D), and pycnidia were quickly formed inside the dead tissue at 11 to 12 dpi (Fig. 2G). This suggests that the environment immediately surrounding dead tissue is suitable for fungal nutrition and that growth occurs at the leading margins of lesion formation in the presence of host cells that have been triggered to die or are in the initial stages of cell death. Hyphae appeared in the form of hunger mycelia outside of the original infiltration area and beyond the lesion at 20 dpi (Fig. 2H).

This is consistent with the view that L. maculans acquires nutrients from plant cells prior to their death, which leads to fungal proliferation into healthy tissue beyond the lesion. It was reported previously that mesophyll and cortical cells at the hyphal front remained alive during systemic infection and that death of host cells occurred 1 to $2 \mathrm{~mm}$ behind the leading hyphal tip in susceptible B. napus (Hammond and Lewis 1987; Hammond et al. 1985). As indicated by Jennings and Lysek (1996), the absorption of nutrients by filamentous fungi occurs immediately distal to the growing hyphal tip. These observations are consistent with our results in leaf tissue, where hyphae were associated with potentially apoptotic cells prior to lesion formation (Fig. 2). Nutrients may be transported in mycelium several millimeters per day by active and passive processes (Davison and Olsson 2000). It is possible that nutrients acquired by the mycelium from apoptotic cells near the leading edge of hyphal growth are metabolized in the absorption zone to energy, and then used to build cell membrane and wall precursors that are transported to growing hyphal tips several 
millimeters from the zone of absorption (Jennings and Lysek 1996; Mennink-Kersten et al. 2004).

Current literature indicates a growing consensus that activation or suppression of apoptosis-like PCD may underlie many plant-pathogen interactions, as it does in animals (Buckner et al. 2000; Danon et al. 2000; Gilchrist 1997, 1998; Gilchrist et al. 2002; Greenberg and Yao 2004; Hansen 2000; Heath 1998; Lam et al. 2001; Yao et al. 2001, 2002). Our results support the hypothesis that $L$. maculans induces B. napus leaf cells to die by apoptosis as part of its process of pathogenesis, and the apoptotic cells provide a source of nutrition for the invading mycelium at the leading edge of the infection before terminal collapse and lesions appear. In addition to tetrapeptide-CHO suppression of PCD in plants, genetic approaches have provided analogous data and disease suppression. For instance, genetic transformation of tomato with the baculovirus-encoded caspaseinhibitor gene $p 35$ provided resistance in tomato to the fungal pathogen Alternaria alternata (Lincoln et al. 2002). Hence, general and robust resistance to such pathogens may be possible by manipulation of key determinants in the apoptotic pathway in such a way that normal plant developmental processes are not influenced.

\section{MATERIALS AND METHODS}

Pycnidiospore inoculum production from $L$. maculans.

Pycnidiospores of L. maculans were isolated from leaf samples collected from naturally infected susceptible $B$. napus canola plants at the University of Western Australia, Shenton Park Field Station. A single pycnidiospore-derived virulent isolate was stored as frozen mycelium on pieces of V8 medium or dried mycelium and pycnidia on filter paper. Inoculum was prepared using a method modified from Mengistu and associates (1993). A spore suspension was produced from an actively growing culture on V8-juice agar, and spread onto V8juice agar plates that were incubated at $22^{\circ} \mathrm{C}$ under continuous fluorescent light and black light (Phillips TL 40W/80RS F40 BLB) in a growth chamber. A dense lawn of mature pycnidia was present on plates after 7 days. The V8 plate was washed with $10 \mathrm{ml}$ of sterile deionized (DI) water and pycnidiospores were released by gently rubbing the agar surface with a bent glass rod. The spore suspension was filtered through sterile Miracloth (CalBiochem, La Jolla, CA, U.S.A.) and adjusted to a standard concentration of $10^{5}$ spores $/ \mathrm{ml}$, or other concentrations as required, using a hemacytometer. The spore suspension was stored in $1.5-\mathrm{ml}$ tubes at $-20^{\circ} \mathrm{C}$ for a maximum of 6 months. Tubes were removed from the freezer for individual experiments and thawed for $15 \mathrm{~min}$ at room temperature, and the inoculum was used for leaf infiltration as described below.

\section{Plant growth and inoculation.}

Seed of susceptible B. napus cv. Westar were sown into steam-treated potting mix (composted pine bark/cocoa peat/river sand, 2:1:1) in free-draining black plastic pots ( 7 by 7 by $10 \mathrm{~cm}$ ). Seedlings were thinned to one plant per pot 7 days after sowing. Plants were grown in a controlled environment room at $20^{\circ} \mathrm{C}$ (day) and $15^{\circ} \mathrm{C}$ (night), with a 12 - and 12 $\mathrm{h}$ photoperiod (day and night, respectively) at a light intensity of $150 \mu \mathrm{Em}^{-2} \mathrm{~s}^{-1}$. Plants were watered daily with DI water and fertilized weekly with general-purpose fertilizer (Thrive, Yates, Australia).

The method of inoculation of leaves with pycnidiospore suspensions of $L$. maculans was based on the leaf infiltration method of Fristensky and associates (1999) which was modified to deliver approximately $15 \mu \mathrm{l}$ at $10^{5}$ spores $/ \mathrm{ml}$ from a $1-\mathrm{cm}^{3}$ needleless syringe. Preliminary inoculum titration experiments indicated that disease could be reproduced on B. napus cv.
Westar at a much lower concentration than used by Fristensky and associates (1999), who used $10^{7}$ spores $/ \mathrm{ml}$. Four-week-old plants were inoculated with a pycnidiospore suspension of $L$. maculans on the third expanded leaf at up to four locations on each side of the midvein. The spore suspension was infiltrated into the lower surface of leaves at locations chosen to avoid the large side veins that limited fungal growth potential. The infiltration area appeared water soaked in an area of approximately $1 \mathrm{~cm}$ in diameter. The border of each water-soaked area was marked with a permanent black marker pen. Spore suspensions were filtered through Millipore filter paper and the sterile filtrate was used as the control inoculation on at least one site per leaf. Inoculated plants were subject to enhanced humidity for $96 \mathrm{~h}$ by placing the plants above a water layer in a sealed clear plastic tub in the controlled-environment room.

\section{Light-microscopic observations of intact infected leaf tissue.}

Observations were made from three separate experiments in which two plants were inoculated on leaf 3 following the standard leaf infiltration method at $10^{5} \mathrm{spores} / \mathrm{ml}$, with one control (filtrate only) inoculation on each leaf. Leaves were sampled on a daily basis from 1 to $14 \mathrm{dpi}$ and at $20 \mathrm{dpi}$. The marked infiltrated areas were cut from leaves and placed directly into a clearing and staining solution with chloral hydrate and trypan blue (Bruzzese and Hasan 1983). The excised leaf pieces were vacuum infiltrated for $10 \mathrm{~min}$ and kept immersed in the solution for 3 days. Leaf pieces were removed and rinsed with DI water twice and reimmersed in a saturated solution of chloral hydrate $(2.5 \mathrm{~g} / \mathrm{ml}$ of DI) to decolorize the tissue. Leaf samples were then mounted in water and examined and photographed under bright-field illumination using a Zeiss Axioplan 2 microscope with an AxioCam Digital photograph system.

In addition, infiltrated leaf pieces were hand sectioned at 25 to $30 \mu \mathrm{m}$ immediately after removal from the leaf, without staining, and auto fluorescence was examined using the same microscope but illuminated with UV light passed through an exciter filter (G365) and a barrier filter (LP397).

\section{Light-microscopic observation of sections of infected leaf tissue.}

Inoculated leaves were sampled for internal anatomical examination at 3, 5, 7, 9, and $11 \mathrm{dpi}$. Fresh leaf segments (4 $\mathrm{mm}^{2}$ ) from infiltration sites were vacuum infiltrated for $10 \mathrm{~min}$ and fixed in $2.5 \%$ glutaraldehyde in $0.05 \mathrm{M}$ phosphate buffer ( $\mathrm{pH} 7.0$ ). After $24 \mathrm{~h}$, the samples were rinsed and dehydrated through a solvent series before embedding in glycol methacrylate (O'Brien and McCully 1981). Semithin cross-sections (2 $\mu \mathrm{m})$ were cut with glass knives on a Sorvall microtome and stained with $0.5 \%$ toluidine blue $\mathrm{O}, \mathrm{pH} 4.4$ (O'Brien and McCully 1981). Cross sections were studied and photographed under white light illumination using the same microscope and digital photograph system as described above.

\section{Identification of apoptotic cells by TUNEL assay.}

Positive results from a preliminary experiment with TUNEL reagents (ApopTag Plus fluorescein in situ apoptosis detection kit; Chemicon, Temecula, CA, U.S.A.) on inoculated leaf tissue sampled at 9, 10, and 11 dpi were used to design the main experiment. Leaf tissue at $10 \mathrm{dpi}$ was hand sectioned at 20- to $30-\mu \mathrm{m}$ thickness. Sections were made from four infiltration sites of two leaves. Two groups of six sections from each infiltration site were obtained. One group was treated directly on the slides with DAPI at $0.5 \mu \mathrm{g} / \mathrm{ml}$ to stain the nuclei, and the other group was examined by the TUNEL reaction. Tissue sections were fixed in $1 \%$ paraformaldehyde in phosphate-buffered saline (PBS) (50 mM sodium phosphate, $200 \mathrm{mM} \mathrm{NaCl}$, 
$\mathrm{pH} 7.4$ ) in a petri dish for $10 \mathrm{~min}$ at room temperature (approximately $20^{\circ} \mathrm{C}$ ) and washed in two changes of PBS for $5 \mathrm{~min}$ each wash. Sections were then postfixed in precooled ethanol/ acetic acid (2:1) for $5 \mathrm{~min}$ at $-20^{\circ} \mathrm{C}$, washed in two changes of PBS for 5 min each wash, then mounted on slides.

Water-treated leaf sections were used for the noninoculated control. Female rodent mammary gland tissue which had 1 to $2 \%$ apoptotic cells was used as a positive control. The sections from an infiltration site incubated without terminal deoxynucleotidyl transferase (TdT) were employed as a negative control. TUNEL reaction was carried out using the components and protocols of the TUNEL kit (Chemicon). In brief, specimens on slides were pretreated with proteinase $\mathrm{K}(20 \mu \mathrm{g} / \mathrm{ml})$ for $15 \mathrm{~min}$ at room temperature, then washed with PBS buffer and equilibration buffer before adding TdT. The reaction mixture containing TdT was incubated in a humidified chamber at $37^{\circ} \mathrm{C}$ for $1 \mathrm{~h}$ and the reaction was stopped by adding stop or wash buffer. The specimens were then mounted and incubated with anti-digoxigenin-fluorescein antibody conjugate for 30 min at room temperature in the dark. After washing three times with PBS, the slides were viewed by fluorescence microscopy. For observation of TUNEL staining, a filter with excitation wavelength of 450 to $490 \mathrm{~nm}$ and emission wavelength of 515 to $565 \mathrm{~nm}$ was used. For observation of DAPI staining, a filter with an excitation wavelength of $365 \mathrm{~nm}$ and an emission wavelength of $397 \mathrm{~nm}$ was used.

\section{Detection of DNA laddering.}

Fresh leaf tissue was cut from the infiltration area of inoculated $\left(10^{5}\right.$ conidia/ml) and control (water only) plants at 5, 7, 9, and $11 \mathrm{dpi}$ and $5 \mathrm{~g}$ was ground in liquid nitrogen to a fine powder with $2.5 \mathrm{~g}$ of polyvinyl-polypyrrolidone in a mortar and pestle. The powder was transferred to a $50-\mathrm{ml}$ centrifuge tube and mixed with $23 \mathrm{ml}$ of prewarmed $\left(65^{\circ} \mathrm{C}\right)$ extraction buffer (100 mM Tris-HCl [pH 8.0], $50 \mathrm{mM}$ EDTA [pH 8.0], $500 \mathrm{mM} \mathrm{NaCl}, 1.25 \%$ SDS [wt/vol], $0.5 \% \mathrm{Na}$ bisulfite, and $2 \%$ 2-mercaptoethanol), shaken well, and heated in a $65^{\circ} \mathrm{C}$ water bath for $20 \mathrm{~min}$, inverting the tube every few minutes. After heating, $7.1 \mathrm{ml}$ of $5 \mathrm{M} \mathrm{KOAc}$ was added, and the tube was inverted several times and placed on ice for $20 \mathrm{~min}$ prior to centrifuging at $2,500 \times g$ for $10 \mathrm{~min}$ at $4^{\circ} \mathrm{C}$. The supernatant was filtered through Miracloth and 0.7 volumes of isopropanol were added before centrifuging again at 2,500 $\times g$ for $10 \mathrm{~min}$ at $4^{\circ} \mathrm{C}$. The pellet was washed twice with $70 \%$ ethanol before mixing with $0.72 \mathrm{ml}$ Tris-EDTA (TE) $(10 \mathrm{mM}$ Tris- $\mathrm{HCl}[\mathrm{pH}$ 8.0] and $1 \mathrm{mM}$ EDTA) and incubated for 5 to $10 \mathrm{~min}$ in a $65^{\circ} \mathrm{C}$ water bath until the pellet dispersed. The resulting solution was transferred to a 2-ml centrifuge tube and $0.48 \mathrm{ml}$ of $7.5 \mathrm{M}$ $\mathrm{NH}_{4} \mathrm{OAc}$ was added and centrifuged at full speed for $5 \mathrm{~min}$ in a microfuge. The supernatant was transferred to a clean 2-ml tube, mixed with $0.75 \mathrm{ml}$ of isopropanol, and incubated on ice for $1 \mathrm{~h}$ before centrifuging at full speed for $5 \mathrm{~min}$ in a microfuge. The pellet was washed twice with $70 \%$ ethanol, resuspended in $400 \mu \mathrm{l}$ of TE and $10 \mu \mathrm{l}$ of RNAase A $(5 \mathrm{mg} / \mathrm{ml})$, and incubated for $15 \mathrm{~min}$ at $37^{\circ} \mathrm{C}$. An aliquot of $20 \mu \mathrm{l}$ of the solution was added to a $1.3 \%$ agarose gel for electrophoresis and observation of DNA laddering.

\section{Effect of caspase inhibitor Ac-DEVD-CHO on leaf lesion development.}

The caspase inhibitor Ac-DEVD-CHO or the substrate AcDEVD-AMC (Calbiochem, U.S.A.) was added to the pycnidiospore suspension to make "fungus plus inhibitor" ("+CHO") or "fungus plus substrate" ("+AMC") solutions with a final concentration of $10^{5}$ spores $/ \mathrm{ml}$ and $100 \mu \mathrm{M}$ inhibitor or substrate. The fungus-only treatment was $10^{5}$ spores $/ \mathrm{ml}$ suspension without inhibitor or substrate. Water-only or aqueous solutions (100 $\mu \mathrm{M})$ of the caspase inhibitor Ac-DEVD-CHO and caspase substrate Ac-DEVD-AMC were used as negative controls.

Three inoculation treatments, $+\mathrm{CHO},+\mathrm{AMC}$, and fungus only, were arranged in pairs on each side of the midvein of leaf 3 on 104 -week-old Westar plants. The three possible pairs of treatments $(+\mathrm{CHO}$ versus $+\mathrm{AMC},+\mathrm{CHO}$ versus fungus only, and fungus only versus $+\mathrm{AMC}$ ) were randomized in positions at the top, middle, and base of each leaf. Following the standard method of leaf infiltration, $15 \mu$ l of each solution $(+\mathrm{CHO}$, $+\mathrm{AMC}$, and fungus only) was infiltrated into the intercellular spaces of the mesophyll of leaf 3. Plants were subjected to enhanced humidity in the growth chamber for 4 days. Symptom development was observed from 1 to $14 \mathrm{dpi}$. At early time points, the infiltrated area contained small circular spots. The diameter of each spot within an infiltrated area was measured by ruler to the nearest millimeter and the estimated circular areas were summed to give a total lesion area for that inoculation. Over time, the spots coalesced within the infiltration area but these lesions were not uniform in shape. Lesion length and width (in millimeters) were measured and used to estimate lesion area according to the closest regular shape (rectangular or circular).

Negative controls were tested separately in pair-wise combination with the spore-containing test mixtures and, in these infiltrations, there was no visible effect of the peptides or the infiltration by water alone, without spores present. Data were analyzed by pairwise Student's $t$ tests in each of the three pairs of treatments using GenStat 6.1 software (VSN International Ltd., Hemel Hempstead, U.K.). Comparisons between means were based on the least significant difference test at the $5 \%$ probability level.

\section{Effect of caspase inhibitor Ac-DEVD-CHO and substrate Ac-DEVD-AMC on fungal growth in vitro.}

The effect of caspase inhibitor Ac-DEVD-CHO and substrate Ac-DEVD-AMC on in vitro growth and survival of L. maculans was assessed in two ways. First, spore germination and fungal growth were examined in the presence or absence of Ac-DEVDCHO or Ac-DEVD-AMC. A drop $(10 \mu \mathrm{l})$ of +CHO, +AMC, and fungus-only spore suspension was placed on a glass slide, covered with cover slip, and kept in a petri dish on moist filter paper at room temperature in a laboratory. Spore germination and hyphal growth were examined after $48 \mathrm{~h}$. Second, the impact of Ac-DEVD-CHO and Ac-DEVD-AMC on fungal growth in vivo was assessed by excision of leaf discs from areas infiltrated with fungus only, $+\mathrm{CHO}$, or $+\mathrm{AMC}$ at 2 dpi followed by incubation on water agar plates. Incubation conditions were the same as for the spore germination test.

\section{ACKNOWLEDGMENTS}

C. Li was supported by an International Postgraduate Research Scholarship at The University of Western Australia (UWA) and a travel grant from Australian Research Council Linkage International Grant LX0346900. We thank J. Kuo and J. Murphy at the Centre for Microscopy and Microanalysis, UWA, for advice on the microscopy work, and $\mathrm{H}$. Li for helpful discussions.

\section{LITERATURE CITED}

Bozhkov, P. V., Suarez, M. F., Filonova, L. H., Daniel, G., Zamyatnin, Jr., A. A., Rodriguez-Nieto, S., Zhivotovsky, B., and Smertenko, A. 2005. Cysteine protease mcII-Pa executes programmed cell death during plant embryogenesis. Proc. Natl. Acad. Sci. U.S.A. 102:14463-14468.

Bruzzese, E., and Hasan, S. 1983. A whole leaf clearing and staining technique for host specificity studies of rust fungi. Plant Pathol. 32:335-338.

Buckner, B., Johal, G. S., and Janick-Buckner, D. 2000. Cell death in maize. Physiol. Plant. 108:231-239.

Chen, S. and Dickman, M. B. 2004. Bcl-2 family members localize to tobacco chloroplasts and inhibit programmed cell death induced by chlo- 
roplast-targeted herbicides. J. Exp. Bot. 55:2617-2623.

Chichkova, N. V., Kim, S. H., Titova, E. S., Kalkum, M., Morozov, V. S., Rubtsov, Y. P., Kalinina, N. O., Taliansky, M. E., and Vartapetian, A. B. 2004. A plant caspase-like protease activated during the hypersensitive response. Plant Cell 16:157-171.

Danon, A., Delorme, V., Mailhac, N., and Gallois, P. 2000. Plant programmed cell death: a common way to die. Plant Physiol. Biochem. 38:647-655

Davison, F. A., and Olsson, S. 2000. Translocation induced outgrowth of fungi in nutrient-free environments. J. Theor. Biol. 205:73-84.

Dickman, M. B., Paark, Y. K., Oltersdorf, T., Li, W., Clemente, T., and French, R. 2001. Abrogation of disease development in plants expressing animal antiapoptotic genes. Proc. Natl. Acad. Sci. U.S.A. 98:69576962

Earnshaw, W. C., Martins, L. M., and Kaufmann, S. H. 1999. Mammalian caspases: structure, activation, substrates, and functions during apoptosis. Annu. Rev. Biochem. 68:383-424.

Fitt, B. D. L., Brun, H., Barbetti, M. J., and Rimmer, S. R. 2006. Worldwide importance of Phoma stem canker (Leptosphaeria maculans and L. biglobosa) on oilseed rape (Brassica napus). Eur. J. Plant Pathol. $114: 3-15$.

Fristensky, B., Balcerzak, M., He, D., and Peijun, Z. 1999. Expressed sequence tags from the defense response of Brassica napus to Leptosphaeria maculans. Mol. Plant Pathol. mppol/1999/0301fristensky. Published online.

Garcia-Calvo, M., Peterson, E. P., Leiting, B., Ruel, R., Nicholson, D. W., and Thornberry, N. A. 1998. Inhibition of human caspases by peptidebased and macromolecular inhibitors. J. Biol. Chem. 273:32608-32613.

Gavrieli, Y., Sherman, Y., and Ben-Sasson, S. A. 1992. Identification of programmed cell death in situ via specific labeling of nuclear DNA fragmentation. J. Cell Biol. 119:493-501.

Gilchrist, D. G. 1997. Mycotoxins reveal connections between plants and animals in apoptosis and ceramide signaling. Cell Death Differ. 4:689698

Gilchrist, D. G. 1998. Programmed cell death in plant disease: the purpose and promise of cellular suicide. Annu. Rev. Phytopathol. 36:393-414.

Gilchrist, D. G., Lincoln, J. E. and Richael, C. 2001. Inhibiting apoptosis in plants using a baculovirus p35 protease inhibitor gene. United States Patent 6310273

Gilchrist, D. G., Lincoln, J. E., and Bostock, R. M. 2002. Apoptotic regulatory factors in plants are targets for engineering novel disease resistance. In: Proc. 12th Australas. Plant Breed. Conf. Perth, Western Australia.

Green, D. R. 1998. Apoptotic pathways: the roads to ruin. Cell 94:695-

Greenberg, J. T., and Yao, N. 2004. The role and regulation of programmed cell death in plant-pathogen interactions. Cell Microbiol. 6:201-211.

Grütter, M. G. 2000. Caspases: key players in programmed cell death Curr. Opin. Struct. Biol. 10:649-655.

Hammond, K. E., and Lewis, B. G. 1986. Ultrastructural studies of the limitation of lesions caused by Leptosphaeria maculans. Physiol. Mol. Plant. Pathol. 28:251-265.

Hammond, K. E., and Lewis, B. G. 1987. The establishment of systemic infection in leaves of oilseed rape by Leptosphaeria maculans. Plant Pathol. 36:135-147

Hammond, K. E., Lewis, B. G., and Musa, T. M. 1985. A systemic pathway in the infection of oilseed rape plants by Leptosphaeria maculans. Plant Pathol. 34:557-565.

Hansen, G. 2000. Evidence for Agrobacterium-induced apoptosis in maize cells. Mol. Plant-Microbe Interact. 13:649-657.

Harvey, J. J. W., Lincoln, J. E., and Gilchrist D. G. 2008. Programmed cell death suppression in transformed plant tissue by tomato cDNAs identified from an Agrobacterium rhizogenes-based functional screen. Mol. Genet. Genomics 279:509-521

Heath, M. C. 1998. Apoptosis, programmed cell death and the hypersensitive response. Eur. J. Plant Pathol. 104:117-124.

Hengartner, M. O. 2000. The biochemistry of apoptosis. Nature 407:770776

Hoat, T. X., Nakayashiki, H., Tosa, Y., and Mayama, S. 2006. Specific cleavage of ribosomal RNA and mRNA during victorin-induced apoptotic cell death in oat. Plant J. 46:922-933.

Howlett, B., J. 2004. Current knowledge of the interaction between Brassica napus and Leptosphaeria maculans. Can. J. Plant Pathol. 26:245252.

Jennings, D. H., and Lysek, G. 1996. Fungal Biology. BIOS Scientific Publishers Ltd., Oxford

Kerr, J. F. R., Wyllie, A. H., and Currie, A. R. 1972. Apoptosis: a basic biological phenomenon with wide ranging implications in tissue kinetics. Br. J. Cancer 26:239-257.
Kiba, A., Sangawa, Y, Ohnishi, K, Yao, N., Park, P., Nakayashiki, H., Tosa, Y., Mayama, S., and Hikichi, Y. 2006. Induction of apoptotic cell death leads to the development of bacterial rot caused by Pseudomonas cichorii. Mol. Plant-Microbe Interact. 19:112-122.

Kuroyanagi, M., Yamada, K., Hatsugai, N., Kondo, M., Nishimura, M. and Hara-Nashimura, I. 2005. Vacuolar processing enzyme is essential for mycotoxin-induced cell death in Arabidopsis thaliana. J. Biol. Chem. 280:32914-32920.

Lam, E. 2005. Vacuolar proteases livening up programmed cell death. Trends Cell Biol. 15:124-127.

Lam, E., Kato, N., and Lawton, M. 2001. Programmed cell death, mitochondria and the plant hypersensitive response. Nature 411:848-853.

Lincoln, J. E., Richael, C., Overduin, B., Smith, K., Bostock, R., and Gilchrist, D. G. 2002. Expression of the antiapoptotic baculovirus p35 gene in tomato blocks programmed cell death and provides broad-spectrum resistance to disease. Proc. Natl. Acad. Sci. U.S.A. 99:1521715221.

Lombardi, L., Ceccarelli, N., Picciarelli, P., and Lorenzi, R. 2007. Caspase-like proteases involvement in programmed cell death of Phaseolus coccineus suspensor. Plant Sci. 172:573-578.

Meier, P., Finch, A., and Evan, G. 2000. Apoptosis in development. Nature 407:796-801

Mengistu, A., Rimmer, S. R., and Williams, P. H. 1993. Protocols for in vitro sporulation, ascospore release, sexual mating, and fertility in crosses of Leptosphaeria maculans. Plant Dis. 77:538-540.

Mennink-Kersten, M. A. S. H., Donnelly, P. J., and Verweij, P. E. 2004 Detection of circulating galactomannan for the diagnosis and management of invasive aspergillosis. Lancet Infect. Dis. 4:349-357.

Mitsuhara, I., Malik, K. A., Miura, M. and Ohashi, Y. 1999. Animal celldeath suppressors Bcl- $\mathrm{X}_{\mathrm{L}}$ and Ced-9 inhibit cell death in tobacco plants. Curr. Biol. 9:775-778.

Navarre, D. A., and Wolpert, T. J. 1999. Victorin induction of an apoptotic/senescence-like response in oats. Plant Cell 11:237-249.

Nicholson, D. W., and Thornberry, N. A. 1997. Caspases: killer proteases. Trends Biochem. Sci. 22:299-306.

Nicholson, D. W., Ali, A., Thornberry, N. A., Vaillancourt, J. P., Ding, C. K., Gallant, M., Gareau, Y., Griffin, P. R., Labelle, M., Lazebnik, Y. A., Munday, N. A., Raju, S. M., Smulson, M. E., Yamin, T.-T., Yu, V. L., and Miller, D. K. 1995. Identification and inhibition of the ICE/CED-3 protease necessary for mammalian apoptosis. Nature 376:37-43.

O'Brien, T., and McCully, M. 1981. The Study of Plant Structure: Principles and Selected Methods. Termarcarphi Pty Ltd., Melbourne, Australia.

Oliver, R., and Ipcho, S. 2004. Arabidopsis pathology breathes new life into the necrotrophs-vs.-biotrophs classification of fungal pathogens. Mol. Plant Pathol. 5:374-352.

Punithalingam, E., and Holliday, P. 1972. Leptosphaeria maculans. In: CMI Descriptions of Pathogenic Fungi and Bacteria No. 331. Anonymous, eds. Commonwealth Mycological Institute, Ferry Lane, Kew, Surrey, London and Reading, England.

Qiao, L., Yacoub, A., Studer, E., Gupta, S., Pei, X. Y., Grant, S., Hylemon, P. B. and Dent, P. 2002. Inhibition of the MAPK and PI3K pathways enhances UDCA-induced apoptosis in primary rodent hepatocytes. Hepatology 35:779-789.

Richael, C., and Gilchrist, D. G. 1999. The hypersensitive response: A case of hold or fold? Physiol. Mol. Plant Path. 55:5-12.

Richael, C., Lincoln, J. E., Bostock, R. M., and Gilchrist, D. G. 2001. Caspase inhibitors reduce symptom development and limit bacterial proliferation in susceptible plant tissue. Physiol. Mol. Plant Pathol. 59:213-221.

Rojo, E., Martin, R., Carter, C., Zouhar, J., Pan, S., Plotnikova, J., Jin, H., Paneque, M., Sánchez-Serrano, J. J., Baker, B., Ausubel, F. M., and Raikhel, N. V. 2004. VPE $\gamma$ exhibits a caspase-like activity that contributes to defense against pathogens. Curr. Biol. 14:1897-1906.

Rouxel, T., and Balesdent, M. H. 2005. The stem canker (blackleg) fungus, Leptosphaeria maculans, enters the genomic era. Mol. Plant Pathol. 6:225-241.

Samadi, L., and Behboodi, B. S. 2006. Fusaric acid induces apoptosis in saffron root-tip cells: roles of caspase-like activity, cytochrome c, and $\mathrm{H}_{2} \mathrm{O}_{2}$. Planta 225:223-234.

Sánchez-Alcázar, J. A., Rodríguez-Hernández, A., Cordero, M. D., Fernández-Ayala, D. J. M., Brea-Calvo, G., Garcia, K., and Navas, P. 2007. The apoptotic microtubule network preserves plasma membrane integrity during the execution phase of apoptosis. Apoptosis 12:11951208

Stennicke, H. R., and Salvesen, G. S. 1998. Properties of the caspases. Biochim. Biophys. Acta 1387:17-31.

Wang, H., Li, J., Bostock, R. M., and Gilchrist, D. G. 1996. Apoptosis: A functional paradigm for programmed plant cell death induced by a hostselective phytotoxin and invoked during development. Plant Cell 8:375391. 
Wei, Y., Fox, T., Chambers, S. P., Sintchak, J., Coll, J. T., Golec, J. M. Swenson, L., Wilson, K. P., and Charifson, P. S. 2000. The structures of caspases- $1,-3,-7$ and -8 reveal the basis for substrate and inhibitor selectivity. Chem. Biol. 7:423-432.

Wolpert, T. J., Dunkle, L. D. and Ciuffetti, L. M. 2002. Host-selective toxins and avirulence determinants: What's in a name? Annu. Rev. Phytopathol. 40:251-285.

Woltering, E. J., van der Bent, A., and Hoeberichts, F. A. 2002. Do plant caspases exist? Plant Physiol. 130:1764-1769.

Wyllie, A. H., Kerr, J. F. R., and Currie, A. R. 1980. Cell death: the significance of apoptosis. Int. Rev. Cytol. 68:251-306.
Xu, P., Rogers, S. J., and Roossinck, M. J. 2004. Expression of antiapoptotic genes $b c l-x L$ and $c e d-9$ in tomato enhances tolerance to viralinduced necrosis and abiotic stress. Proc. Natl. Acad. Sci. U.S.A. 101:15805-15810.

Yao, N., Tada, Y., Park, P., Nakayashiki, H., Tosa, Y., and Mayama, S. 2001. Novel evidence for apoptotic cell response and differential signals in chromatin condensation and DNA cleavage in victorin-treated oats. Plant J. 28:13-26.

Yao, N., Imai, S., Tada, Y., Nakayashiki, H., Tosa, Y., Park, P., and Mayama, S. 2002. Apoptotic cell death is a common response to pathogen attack in oats. Mol. Plant-Microbe Interact. 15:1000-1007. 